\title{
TINJAUAN URGENSI RANCANGAN UNDANG-UNDANG CONTEMPT OF COURT (TINDAK PIDANA PENYELENGGARAAN PERADILAN) DALAM SISTEM PERUNDANG-UNDANGAN NASIONAL
}

Oleh :

\author{
Bayu Dwi Anggono ${ }^{1}$
}

Fakultas Hukum Universitas Jember

\begin{abstract}
Abstrak
Beredarnya draft Rancangan Undang-Undang (RUU) Tindak Pidana Penyelenggaraan Peradilan (Contempt of Court) beberapa saat lalu mengejutkan publik. RUU ini telah masuk dalam Program Legislasi Nasional (Prolegnas) 2015-2019 sebagai usulan DPR. Potensi permasalahan utama terhadap harmonisasi sistem perundang-undangan nasional, pengakuan, penghormatan, perlindungan dan pemenuhan hak asasi manusia sebagaimana dijamin oleh Undang-Undang Dasar Negara Republik Indonesia Tahun 1945. Dengan adanya sejumlah ketentuan tentang tindak pidana penyelenggaraan peradilan di dalam Kitab Undang-Undang Hukum Pidana, Kitab Undang-Undang Hukum Acara Pidana serta dalam Undang-Undang Kekuasaan Kehakiman, maka urgensi pembahasan RUU Contempt of Court dalam sistem perundang-undangan nasional menjadi penting untuk dianalisis.
\end{abstract}

Kata Kunci: RUU, Tindak Pidana Penyelenggaraan Peradilan, Program Legislasi Nasional

\section{Abstract}

Public were surprised by the circulation of a bill (RUU) concerning Contempt of Court. This bill has been inserted into the National Legislation Program (Prolegnas) 2015-2019 as the proposal from Parliament. Potential major problems to the system of harmonization of national legislation, recognition, respect, protection and fulfillment of human rights as guaranteed by the 1945 Constitution of the Republic of Indonesia. The existing provisions of contempt of court in Indonesian Criminal Code, Indonesian Criminal Procedure Code, and Judicial Power Act, lead to the need to analize the urgency of discussing such bill in the national legislation system.

Keywords: Bill, Contempt of Court, National Legislation Program

\section{Pendahuluan}

\section{Latar belakang}

Indonesia merupakan negara hukum, salah satu cirinya adalah adanya peradilan yang bebas dan tidak memihak. ${ }^{2}$ Dikarenakan fungsinya untuk memberikan keadilan atas perselisihan berbagai pihak, keberadaan lembaga peradilan itu haruslah bebas dari campur tangan kekuasaan yang berada di luar dirinya. ${ }^{3}$ Konstitusi Indonesia menghendaki kebebasan dalam

${ }^{1}$ Bayu Dwi Anggono adalah dosen Ilmu Perundang-undangan, Direktur Pusat Pengkajian Pancasila dan Konstitusi (Puskapsi) Fakultas Hukum Universitas Jember.

2 A. V Dicey dalam Moh. Mahfud MD, 2012, Membangun Politik Hukum, Menegakkan Konstitusi, Jakarta: Rajawali Press, h. 90, menguraikan adanya tiga ciri penting, dalam setiap Negara Hukum yang disebutnya dengan istilah "The Rule of Law", yaitu: Supremacy of law, yaitu supremasi hukum, tidak ada kesewenang-wenangan kekuasaan sehingga orang hanya boleh dihukum jika melanggar hukum; Equality before the law, yaitu adanya kesamaan di depan hukum; Due process of law, terjaminnya hak-hak asasi manusia oleh undang-undang maupun oleh putusan pengadilan.

${ }^{3}$ Ibid, h. 91 


\section{KERTHA PATRIKA}

Volume 38, Nomor 1, Januari-April 2016

kekuasaan kehakiman ini, termasuk adanya pemisahan yang tegas antara fungsi yudikatif dan fungsi eksekutif. ${ }^{4}$

Sebagaimana pernah disampaikan oleh Mantan Ketua Konstituante, Wilopo, pemerintahan konstitusional adalah pemerintah yang dibatasi oleh hukum dan penghormatan terhadap Hak Asasi Manusia (HAM). ${ }^{5}$ Berkaitan dengan lembaga peradilan yang bebas, merdeka, tidak memihak dan bebas dari campur tangan kekuasaan yang ada di luar dirinya, beberapa saat lalu publik dikejutkan dengan beredarnya draft Rancangan Undang-Undang (RUU) Tindak Pidana Penyelenggaraan Peradilan (Contempt of Court). Secara faktual, memang benar RUU ini telah masuk dalam Program Legislasi Nasional (Prolegnas) 2015-2019 sebagai usulan DPR. Kendati demikian bukan berarti bahwa sesuatu yang telah masuk dalam Prolegnas tidak dapat dikritisi atau dikoreksi jika substansinya ternyata mengandung potensi permasalahan.Utamanya terhadap harmonisasi dengan sistem perundang-undangan nasional maupun pengakuan, penghormatan, perlindungan, pemenuhan HAM sebagaimana dijamin oleh UUD NRI Tahun 1945. Dengan munculnya pembahasan tentang contempt of court ini dalam RUU, yang nantinya jika disetujui menjadi UU, jelas akan bermasalah dalam sisi harmonisasi dalam sistem perundang-undangan. Berkenaan dengan beberapa ketentuan peraturan perundangan yang mengatur contempt of court ini. Adapun fokus utama artikel ini adalah mengenai "urgensi RUU Contempt of Court dalam sistem perundang-undangan nasional". Untuk mencapai analisis terkait dengan fokus tersebut, akan dibahas terlebih dahulu mengenai: 1) definisi contempt of court; 2) pengaturan contempt of court dalam UU Kekusaan Kehakiman, KUHP maupun KUHAP, dan 3) potensi overlapping dengan adanya RUU tentang contempt of court.

\section{Pembahasan}

Sebagai catatan awal RUU Tindak Pidana Penyelenggaraan Peradilan bukanlah perintah langsung dari UUD NRI Tahun 1945. Suatu RUU yang tidak diperintahkan langsung untuk dibentuk oleh UUD dapat dibuat sepanjang memenuhi beberapa syarat, yaitu: ${ }^{6}$

a. untuk mengatur lebih lanjut ketentuan dalam UUD 1945;

b. dinyatakan oleh suatu UU untuk diatur dengan UU;

c. materi lain yang berkaitan dengan hak-hak asasi manusia, hak dan kewajiban warga negara, pembagian kekuasaan negara, organisasi pokok lembaga negara, pembagian

${ }^{4}$ lihat, Jimly Asshiddiqie, 2004, Konstitusi dan Konstitusionalisme Indonesia, Jakarta: Mahkamah Konstitusi dan Pusat Studi Hukum Tata Negara FH UI, h. 53. Menurut Jimly Asshiddiqie, terdapat 9 prinsip penyelenggaraan negara, yaitu: Prinsip Ketuhanan Yang Maha Esa; Cita Negara Hukum dan "The Rule of Law"; Paham Kedaulatan Rakyat dan Demokrasi; Demokrasi langsung dan Demokrasi Perwakilan; Pemisahan Kekuasaan dan Prinsip Check and Balances; Sistem Pemerintahan Presidensiil; Persatuan dan Keragaman; Paham Demikrasi Ekonomi dan Ekonomi Pasar Sosial; Cita Masyarakat Madani .

5 Ibid, h. 89

${ }^{6}$ Bayu Dwi Anggono, 2014, Perkembangan Pembentukan Undang-Undang di Indonesia, Konstitusi Press, Jakarta, h. 63-86 
wilayah/daerah negara, pengaturan yang membebani keuangan warga negara.

Apabila pengusul RUU Tindak Pidana Penyelenggaraan Peradilan menyatakan bahwa RUU ini disusun dalam rangka mengatur lebih lanjut ketentuan UUD NRI Tahun 1945 khususnya Pasal 24 tentang kemandirian kekuasaan kehakiman. Maka, terlebih dahulu harus dilakukan penilayan apakah UU yang ada saat ini yaitu UU Nomor 48 Tahun 2009 tentang Kekuasaan Kehakiman sebagai penjabaran ketentuan Pasal 24 UUD 1945 belum mencukupi mengatur mengenai jaminan kemandirian kekuasaan kehakiman.

\section{Pengertian dan Ruang Lingkup Contempt of Court}

Istilah contempt of court dalam RUU contempt of court diartikan sebagai tindak pidana penyelenggaraan peradilan dalam Pasal 1 ayat (2), yaitu setiap perbuatan bersifat intervensi, tindakan, sikap, ucapan, tingkah laku dan/atau publikasi yang bertendensi dapat menghina, merendahkan, terganggunya, dan merongrong kewibawaan, kehormatan dan martabat hakim atau badan peradilan.

Dalam sistem common law, contempt of court diartikan sebagai:

"any act which is calculated to embarras, hinder, or obstruct court in administration of justice or which is calculated to lessen its authority or its dignity. Committed by a person who does any act in willful contravention of its authority or dignit, or tending to impede or frustrate the administration of justice, or by one who, being under the court's authority as a party to a proceeding therein, will fully disobeys its lawful orders or fails to comply with and undertaking which he has given".?

Klasifikasi ini bisa bersifat langsung atau tidak langsung, bersifat pidana atau perdata.

Contempt of Court sebagai pranata hukum muncul dalam sistem common law sekitar abad ke-13 di Inggris tetapi baru dituangkan dalam UU pada tahun $1981 .{ }^{8}$ Pranata hukum ini perlu untuk mengimbangi sistem advesary system yang dianut oleh sistem peradilan mereka. Secara historis fungsi utama pranata ini adalah untuk melindungi wibawa hakim dari suatu sikap, tindak dari siapa saja (advokat, wartawan) selama persidangan. ${ }^{9}$

Dalam sejarahnya, istilah contempt of court di Indonesia pertama kali digunakan dalam penjelasan umum UU No. 14 tahun 1985 tentang Tentang Mahkamah Agung (LNRI Tahun 1985 Nomor 73, TLNRI Nomor 3316) sebagaimana telah diubah terakhir dengan UU Nomor 3 tahun 2009 tentang Perubahan Kedua Atas UU Nomor 14 Tahun 1985 tentang

\footnotetext{
7 Luhut M. P. Pangaribuan, 1996, Advokat dan Contempt of Court Satu Proses di Dewan Kehormatan Profesi, Jakarta: Djambatan, h. 31

8 Background Paper on Freedom of Expression and Contempt of Court, "International Seminar on Promoting Freedom of Expression With the Three Specialised International Mandates” London, United Kingdom, 29-30 November 2000, p. 12 https:// www.article19.org/data/files/pdfs/publications/foe-and-contempt-of-court.pdf, diakses, 30 Januari 2016.

$9 \quad$ Ibid, h. 32
} 


\section{KERTHA PATRIKA}

Volume 38, Nomor 1, Januari-April 2016

Mahkamah Agung (LNRI Nomor 4958). Butir 4 alinea ke-4, menjelaskan; "Selanjutnya untuk dapat lebih menjamin terciptanya suasana yang sebaik-baiknya bagi penyelenggaraan peradilan guna menegakkan hukum dan keadilan berdasarkan Pancasila, maka perlu dibuat suatu UU yang mengatur penindakan terhadap perbuatan, tingkah laku, sikap dan/ atau ucapan yang merendahkan dan merongrong kewibawaan, martabat, dan kehormatan badan peradilan yang dikenal sebagai contempt of court." 10

Berdasarkan penjelasan umum UU No. 14 tahun 1985, butir 4 alinea ke-4 tersebut, sebenarnya UU ini secara eksplisit menghendaki adanya UU khusus yang mengatur tentang contempt of court.

\section{Pengaturan Contempt of Court Dalam UU Kekuasaan Kehakiman, KUHP, KUHAP}

Pasal 3 ayat (1) UU Nomor 48 Tahun 2009 tentang Kekuasaan Kehakiman sebenarnya sudah mengatur dalam menjalankan tugas dan fungsinya, hakim dan hakim konstitusi wajib menjaga kemandirian peradilan. ${ }^{11}$ Adapun yang dimaksud dengan "kemandirian peradilan" adalah bebas dari campur tangan pihak luar dan bebas dari segala bentuk tekanan, baik fisik maupun psikis. Bahkan dalam Pasal 3 ayat (2) UU Kekuasaan Kehakiman secara tegas mencantumkan larangan segala campur tangan dalam urusan peradilan oleh pihak lain di luar kekuasaan kehakiman, kecuali dalam hal-hal sebagaimana dimaksud dalam UUD NRI Tahun 1945. Terhadap pelanggaran secara sengaja terhadap larangan tersebut, Pasal 3 ayat (3) mengatur bahwa hal tersebut dapat dipidana sesuai dengan ketentuan peraturan perundang-undangan.

Pasal 3 ayat (3) UU Kekuasaan Kehakiman secara jelas tidak mendelegasikan mengenai tindak pidana penyelenggaraan peradilan harus diatur dalam UU tersendiri melainkan dapat diatur dalam ketentuan peraturan perundang-undangan lain dalam hal ini adalah KUHP maupun KUHAP. Selama ini tindak pidana penyelenggaraan peradilan telah diatur dalam Pasal 207, Pasal 217, dan Pasal 224 KUHP.

Pasal 207 KUHP mengatur "Barang siapa dengan sengaja di muka umum dengan lisan atau tulisan menghina suatu penguasa atau badan umum yang ada di Indonesia, diancam dengan pidana penjara paling lama satu tahun enam bulan atau pidana denda paling banyak empat ribu lima ratus rupiah". Sementara Pasal 217 KUHP menentukan "Barang siapa menimbulkan kegaduhan dalam sidang pengadilan atau di tempat di mana seorang pejabat sedang menjalankan tugasnya yang sah di muka umum, dan tidak pergi sesudah diperintah

${ }^{10}$ Mengutip buku Naskah Akademis Penelitian Contempt of Court 2002 terbitan Puslitbang Hukum dan Peradilan Mahkamah Agung RI (h. 7) dalam http://www.hukumonline.com/klinik/detail/lt514052dfdcf3b/definisi-contempt-of-court, diakses hari Sabtu, 23 Januari 2016: 12.32

${ }^{11}$ Bahwa kemandirian peradilan tersebut dalam pasal 2 ayat (2) UU No. 48 tahun 2009 adalah untuk mewujudkan "Peradilan negara menerapkan dan menegakkan hukum dan keadilan berdasarkan Pancasila”. Menurut Muladi, 2002, Hak Asasi Manusia, Politik dan Sistem Peradilan Pidana, Semarang: Badan Penerbit Universitas Diponegoro, h. 215. Penegakan hukum yang bersifat praktis harus dihindari, karena mengandung konotasi yang berbau kepastian hukum semata-mata. 
oleh atau atas nama penguasa yang berwenang, diancam dengan pidana penjara paling lama tiga minggu atau pidana denda paling banyak seribu delapan ratus rupiah".

Adapun Pasal 224 KUHP mengatur, "Barang siapa dipanggil sebagai saksi, ahli atau juru bahasa menurut UU dengan sengaja tidak memenuhi kewajiban berdasarkan UU yang harus dipenuhinya, diancam: 1) dalam perkara pidana, dengan pidana penjara paling lama sembilan bulan; 2) dalam perkara lain, dengan pidana penjara paling lama enam bulan".

Begitu pula dalam Pasal 218 KUHAP yang mengatur bahwa: (1) Dalam ruang sidang siapa pun wajib menunjukkan sikap hormat kepada pengadilan; (2) Siapa pun yang di sidang pengadilan bersikap tidak sesuai dengan martabat pengadilan dan tidak menaati tata tertib setelah mendapat peringatan dari hakim ketua sidang, atas perintahnya yang bersangkutan dikeluarkan dari ruang sidang; (3) Dalam hal pelanggaran tata tertib sebagaimana dimaksud dalam ayat (2) bersifat suatu tindak pidana, tidak mengurangi kemungkinan dilakukan penuntutan terhadap pelakunya.

Sistem peradilan yang dijalankan sekarang sesungguhnya tidak memerlukan adanya suatu otoritas contempt of court dimana prosedurnya, summarily, without any hearing or other procedure taking place. Sebab dalam persidangan hakim adalah pemimpin dan menjaga tata tertib persidangan, oleh karenanya segala sesuatunya harus seizinnya dan/atau melaluinya termasuk ketika wartawan hendak meliput, jaksa dan advokat hendak mengajukan pertanyaan (vide pasal 164 ayat (2) KUHAP). ${ }^{12}$

Dalam konteks ada perilaku langsung dan tidak langsung, bersifat pidana atau perdata, siapa saja dalam mengikuti suatu sidang bersikap telah merendahkan, merusak, melecehkan wibawa pengadilan (Hakim), maka Hakim yang telah dengan demikian besar (absolute) kekuasaannya dalam non adversary system diberikan oleh KUHP, dan KUHAP tidak memerlukan lagi kewenangan tambahan. Pasal 217 KUHP jo Pasal 218 KUHP telah memberikan kewenangan kepada Hakim. ${ }^{13}$ Untuk melakukan segala sesuatu jika menurut anggapannya terdapat pihak / seseorang melakukan perbuatan yang mengganggu jalannya persidangan (misal: menimbulkan kegaduhan dalam sidang pengadilan; bersikap tidak sesuai dengan martabat pengadilan dan tidak menaati tata tertib setelah mendapat peringatan dari hakim ketua sidang, atas perintahnya yang bersangkutan dikeluarkan dari ruang sidang). Tentu menjadi berlebihan jika kewenangan ini kemudian diatur tersendiri dalam peraturan perundangan mengenai tindak pidana penyelenggaraan peradilan.

Paul Scholten mengemukakan bahwa hukum adalah sistem yang terbuka, yang tidak hanya melihat ke belakang kepada perundang-undangan yang ada, tetapi juga memandang ke depan dengan memikirkan konsekuensi-konsekuensi suatu putusan hukum bagi masyarakat

\footnotetext{
12 Luhut M. P. Pangaribuan, op.cit, h. 34

13 Ibid, h. 34
} 


\section{KERTHA PATRIKA}

Volume 38, Nomor 1, Januari-April 2016

yang diaturnya. ${ }^{14}$ Sejalan dengan itu, maka tafsir atas ketentuan dalam Pasal 217 KUHP jo Pasal 218 KUHP atas kewenangan hakim dalam rangka mencegah terjadinya contempt of court di peradilan/persidangan.

Sesuai perkembangan zaman beberapa ketentuan tindak pidana penyelenggaraan peradilan dalam KUHP memang perlu untuk disesuaikan. Baik mengenai jenis tindak pidana penyelenggaraan peradilan yang perlu ditambahkan maupun ancaman sanksinya yang perlu ditingkatkan dalam rangka menimbulkan efek gentar, namun bukan berarti hal tersebut dilakukan dengan cara membuat UU Tindak Pidana Penyelenggaraan Peradilan sendiri. RUU KUHP yang saat ini sudah mulai dibahas oleh DPR bersama dengan pemerintah sebenarnya secara sistematis telah memasukkan upaya memperbaharui tindak pidana terkait penyelenggaraan peradilan. Sehingga ketentuan peraturan perundangan yang ada telah cukup mengatur tentang penyelenggaraan tindak pidana peradilan, tanpa perlu dibuat peraturan tersendiri, dengan melalui kontruksi dan interpretasi, ${ }^{15}$ yang dinamakan $\mathrm{Zu}$-Ende-Denken Eines Gedachten, yaitu suatu usaha untuk mencari dengan sungguh-sungguh apa yang sebenarnya dipikirkan oleh pembuat UU melalui karyanya itu.

\section{Overlapping Pengaturan RUU Contempt of Court dengan RUU KUHP}

Dalam RUU KUHP khususnya Buku Kedua tentang Tindak Pidana, para perumus RUU KUHP telah membuat Bab tersendiri tentang Tindak Pidana Proses Peradilan yaitu dalam Bab VI. Tindak Pidana ini diatur mulai Pasal 328 sampai dengan Pasal 345. Perbuatan yang dapat dipidana sesuai pasal-pasal tersebut di antaranya:

a. perbuatan yang mengakibatkan terganggunya proses peradilan;

b. menampilkan diri untuk orang lain sebagai peserta atau sebagai pembantu tindak pidana;

c. tidak mematuhi perintah pengadilan;

d. menghina hakim atau menyerang integritas hakim dalam persidangan;

e. mempublikasikan segala sesuatu yang dapat mempengaruhi sifat tidak memihak hakim dalam sidang pengadilan;

f. menggunakan kekerasan atau ancaman kekerasan atau mengintimidasi penyelidik, penyidik, penuntut umum, advokat, atau hakim;

g. menyampaikan alat bukti palsu;

h. merusak alat bukti atau barang bukti;

i. menyembunyikan orang yang telah melakukan tindak pidana;

j. melepaskan atau memberi pertolongan ketika seseorang meloloskan diri dari penah-

14 Satjipto Rahardjo, 1986, Ilmu Hukum, Bandung: Alumni, h. 136

15 Gustav Radburch dalam Satjipto Rahardjo, Ibid, h. 138

54 Jurnal Ilmiah Fakultas Hukum Universitas Udayana 
anan yang dilakukan atas perintah pejabat yang berwenang;

k. secara melawan hukum tidak datang pada saat dipanggil sebagai saksi;

1. memberikan keterangan palsu di atas sumpah;

m. membocorkan nama/alamat pelapor dalam penyidikan dan pemeriksaan di sidang pengadilan;

n. merusak gedung, ruang sidang pengadilan, atau alat-alat perlengkapan sidang pengadilan;

o. melakukan penyerangan langsung terhadap saksi saat meberikan kesaksiannya, atau aparat penegak hukum dan petugas pengadilan yang sedang menjalankan tugasnya;

p. menghalang-halangi saksi dan/atau korban secara melawan hukum sehingga saksi dan/ atau korban tidak memperoleh perlindungan.

Bahkan Pasal 346 juga mengatur mengenai perluasan tindak pidana terhadap proses peradilan sebagaimana dimaksud dalam Pasal 415, Pasal 417, Pasal 418, Pasal 419, Pasal 427, Pasal 436 ayat (2), Pasal 664, Pasal 670, Pasal 679, Pasal 690 ayat (2), Pasal 697 huruf a dan huruf b, Pasal 697 huruf c, Pasal 697 huruf e, Pasal 716, atau Pasal 717 sepanjang perbuatan itu menyangkut badan peradilan. Badan peradilan sebagaimana dimaksud meliputi Peradilan Umum, Peradilan Agama, Peradilan Tata Usaha Negara, dan Peradilan Militer, Mahkamah Konstitusi, termasuk peradilan lain yang ditentukan dalam UU. Perluasan sebagai contoh adalah dalam Pasal 419 yang mengatur ancaman hukuman bagi setiap orang yang mempergunakan suatu hak, yang diketahuinya bahwa hak tersebut telah dicabut berdasarkan putusan pengadilan.

Pengaturan jenis tindak pidana terkait proses peradilan dalam RUU KUHP jumlahnya sekitar 62 ketentuan. Sementara dalam RUU Tindak Pidana Penyelenggaraan Peradilan tindak pidananya yang diatur sebanyak 60 ketentuan. Meskipun jenis dan jumlah tindak pidana dalam RUU KUHP maupun RUU Tindak Pidana Penyelenggaraan Peradilan jumlahnya hampir sama namun ancaman hukuman dalam RUU KUHP dengan RUU Tindak Pidana Penyelenggaraan Peradilan sangatlah berbeda. Sebagai contoh Pasal 328 RUU KUHP mengatur mengenai ancaman hukuman bagi Setiap orang yang secara melawan hukum melakukan perbuatan yang mengakibatkan terganggunya proses peradilan adalah pidana penjara paling lama 5 (lima) tahun atau pidana denda paling banyak Kategori IV (Rp. 500.000.000).

Sementara dalam Pasal 17 RUU Tindak Pidana Penyelenggaraan Peradilan ancaman terhadap perbuatan yang sama sebagaimana diatur di dalam Pasal 328 RUU KUHP adalah pidana penjara paling lama 6 (enam) tahun atau pidana denda paling banyak Rp.100.000.000,00 (seratus juta rupiah). Perbedaan ancaman hukuman juga berlaku untuk ketentuan lainnya seperti tindak pidana merusak gedung, ruang sidang pengadilan, atau alat-alat perlengkapan sidang pengadilan, dan tindak pidana menghina hakim atau menyerang integritas atau sifat tidak memihak hakim. 


\section{KERTHA PATRIKA}

Volume 38, Nomor 1, Januari-April 2016

Mengingat pertimbangan bahwa saat ini RUU KUHP tengah dalam proses pembahasan di DPR, maka pilihan kebijakan hukum yang paling memungkinkan adalah mengatur tindak pidana proses peradilan dalam RUU KUHP dan bukan dengan RUU Tindak Pidana Penyelenggaraan Peradilan yang berdiri sendiri. Pengaturan di berbagai negara lain mengenai contempt of court sangat bervariasi, ada yang mengatur dalam UU tersendiri, ada pula yang tergabung dalam criminal code. Adapun mengenai pengaturan non pidana yang ada dalam RUU Tindak Pidana Penyelenggaraan Peradilan jika pada akhirnya tidak jadi UU tersendiri seperti ketertiban persidangan, kelancaran persidangan, dan pengamanan persidangan nantinya dapat diatur dengan Peraturan Mahkamah Agung dan Peraturan Mahkamah Konstitusi mengingat Mahkamah Agung dan Mahkamah Konstitusi oleh UU MA dan UU MK diberikan wewenang untuk mengatur lebih lanjut hal-hal yang diperlukan bagi kelancaran pelaksanaan tugas dan wewenangnya.

Argumentasi bahwa tindak pidana proses peradilan perlu diatur, larangan dapat dibenarkan, kendati demikian bukan berarti ketentuan dalam RUU KUHP juga secara keseluruhan dapat diterima. Mengingat terdapat rumusan tindak pidana yang berpotensi multitafsir dalam penerapannya seperti ketentuan Pasal 329 huruf d yang menentukan:

"dipidana dengan pidana penjara paling lama 5 (lima) tahun atau pidana denda paling banyak Kategori IV bagi setiap orang yang secara melawan hukum mempublikasikan atau membolehkan untuk dipublikasikan segala sesuatu yang menimbulkan akibat yang dapat mempengaruhi sifat tidak memihak hakim dalam sidang pengadilan.”

Ketentuan ini menunjukkan perbedaan dengan pidana penghinaan pengadilan di berbagai negara. Pada bagian penjelasan Pasal 329 huruf d tidak memberikan batasan terhadap ketentuan tersebut dan hanya menjelaskan tujuan adanya Pasal ini yaitu untuk melindungi peradilan atau proses sidang pengadilan terhadap perbuatan yang menghina atau menyerang atau merusak kenetralan pengadilan.

Eksistensi Pasal 329 huruf d RUU KUHP ini ancaman hukumannya lebih rendah dibandingkan Pasal 24 RUU Tindak Pidana Penyelenggaraan Peradilan yang mengatur;

"Setiap orang yang mempublikasikan atau memperkenankan untuk dipublikasikan proses persidangan yang sedang berlangsung, atau perkara yang dalam tahap upaya hukum, yang bertendensi dapat mempengaruhi kemerdekaan atau sifat tidak memihak hakim, dipidana dengan pidana penjara paling lama 10 (sepuluh) tahun atau pidana denda paling banyak Rp.1.000.000.000.00,- (satu milyar rupiah).”

Jika pasal ini tidak diperjelas dan dibatasi jangkauan pengaturannya maka akan berpotensi mengancam kebebasan berekspresi warga negara yang dijamin oleh UUD NRI Tahun 1945 termasuk kebebasan Pers. 
Pengaturan tindak pidana proses peradilan haruslah diletakkan dalam kerangka menjaga keseimbangan dan kemandirian kekuasaan kehakiman di satu sisi dan di sisi lain tetap ditempatkan dalam kerangka penghormatan terhadap HAM, diantaranya: hak atas kebebasan mengeluarkan pendapat, hak untuk memperoleh, memiliki, menyimpan, mengolah, dan menyampaikan informasi dengan menggunakan segala jenis saluran yang tersedia, dan hak atas rasa aman dan perlindungan dari ancaman ketakutan untuk berbuat atau tidak berbuat sesuatu yang merupakan HAM. Untuk itu ketentuan tentang larangan untuk mempublikasikan atau membolehkan untuk dipublikasikan segala sesuatu yang menimbulkan akibat yang dapat mempengaruhi sifat tidak memihak hakim dalam sidang pengadilan haruslah dibatasi secara ketat yaitu hanya publikasi yang menciptakan risiko besar terhadap jalannya proses peradilan untuk mencari keadilan seperti publikasi bahwa terdakwa dinyatakan bersalah sebelum sidang berakhir yang dapat dipidana. Pembatasan secara ketat publikasi yang dapat dipidana ini sebagaimana diterapkan dalam The Contempt of Court Act Inggris Tahun 1981. ${ }^{16}$

Pembatasan secara ketat terhadap publikasi yang dapat dikategorikan sebagai Contempt of Court juga diberlakukan di Amerika Serikat yaitu publikasi tidak bisa dikategorikan sebagai penghinaan sampai dapat dibuktikan dengan sangat jelas menghadirkan bahaya bagi proses peradilan. Untuk dapat dihukum harus dibuktikan adanya niat jahat yang sangat serius untuk membahayakan proses peradilan yang sedang berjalan. Secara praktek hukum di Amerika Serikat, ancaman publikasi tidaklah ditujukan bagi media yang mempublikasikan atau melaporkan suatu kasus hukum yang menunggu untuk diputus dengan kontroversi yang terkadang menyertai kasus tersebut. ${ }^{17}$

\section{Penutup}

\section{Kesimpulan}

Contempt of Court merupakan perbuatan bersifat intervensi, tindakan, sikap, ucapan, tingkah laku dan/atau publikasi yang bertendensi dapat menghina, merendahkan, terganggunya, dan merongrong kewibawaan, kehormatan dan martabat hakim atau badan peradilan. Secara normatif bahwa Contempt of Court sudah diatur dalam UU Kekuasaan Kehakiman, KUHP dan KUHAP. Dari pengaturan tersebut terdapat perbedaan kebijakan ancaman hukuman dalam ketentuan pada RUU Contempt of Court dengan RUU KUHP yakni pada rumusan tindak pidana Pasal 329 huruf d yang berpotensi multitafsir dalam penerapannya.

Ketentuan tentang larangan untuk mempublikasikan segala sesuatu yang mempengaruhi sifat tidak memihak hakim dalam sidang pengadilan haruslah dibatasi secara ketat. Dengan cara hanya publikasi yang menciptakan risiko besar terhadap jalannya proses peradilan untuk mencari keadilan seperti publikasi bahwa terdakwa dinyatakan bersalah sebelum

\footnotetext{
16 Background Paper on Freedom of Expression and Contempt of Court, loc.cit.

17 Ibid, p.8
} 


\section{KERTHA PATRIKA}

Volume 38, Nomor 1, Januari-April 2016

sidang berakhir yang dapat dipidana sebagaimana yang telah diterapkan dalam The Contempt of Court Act Inggris Tahun 1981. Sedangkan di Amerika Serikat, ancaman publikasi tidak ditujukan bagi media yang mempublikasikan atau melaporkan suatu kasus hukum yang menunggu untuk diputus dengan kontroversi yang terkadang menyertai kasus tersebut.

Berdasarkan analisis tersebut, eksistensi dari RUU Contempt of Court ini bila menjadi UU berpotensi menciptakan disharmonisasi dan konflik norma dengan UU lainnya. Apalagi RUU Tindak Pidana Penyelenggaraan Peradilan bukanlah perintah langsung dari UUD NRI Tahun 1945. Suatu RUU yang tidak diperintahkan langsung untuk dibentuk oleh UUD dapat dibentuk sepanjang memenuhi syarat yaitu: a. Untuk mengatur lebih lanjut ketentuan dalam UUD NRI Tahun 1945; b. dinyatakan oleh suatu UU untuk diatur dengan UU; c. materi lain yang berkaitan dengan hak-hak asasi manusia, hak dan kewajiban warga negara, pembagian kekuasaan negara, organisasi pokok lembaga negara, pembagian wilayah/daerah negara, pengaturan yang membebani keuangan warga negara. Hal ini tentu mengindikasikan urgensi dilakukannya pembahasan tentang contempt of court.

\section{Saran}

a. Terkait dengan RUU KUHP yang tengah dalam proses pembahasan di DPR, pilihan kebijakan hukum yang paling memungkinkan adalah mengatur tindak pidana penyelenggaraan peradilan dalam RUU KUHP dan bukan dengan RUU Tindak Pidana Penyelenggaraan Peradilan yang berdiri sendiri.

b. Mengenai pengaturan non pidana yang ada dalam RUU Tindak Pidana Penyelenggaraan Peradilan jika nanti pada akhirnya tidak menjadi UU tersendiri, ketertiban persidangan, kelancaran persidangan, dan pengamanan persidangan dapat diatur dengan Peraturan Mahkamah Agung dan Peraturan Mahkamah Konstitusi mengingat kedua lembaga peradilan tersebut diberikan wewenang untuk mengatur lebih lanjut hal-hal yang diperlukan bagi kelancaran pelaksanaan tugas dan wewenangnya.

\section{DAFTAR PUSTAKA}

\section{A. Buku}

Asshiddiqie, Jimly, 2004, Konstitusi dan Konstitusionalisme Indonesia, Jakarta: Mahkamah Konstitusi dan Pusat Studi Hukum Tata Negara FH UI

Mahfud MD, Moh, 2012, Membangun Politik Hukum, Menegakkan Konstitusi, Jakarta: Rajawali Press

Muladi, 2002, Hak Asasi Manusia, Politik dan Sistem Peradilan Pidana, Semarang: Badan Penerbit Universitas Diponegoro

58 | Jurnal Ilmiah Fakultas Hukum Universitas Udayana 
Pangaribuan, Luhut M. P. 1996, Advokat dan Contempt of Court Satu Proses di Dewan Kehormatan Profesi, Jakarta: Djambatan

Rahardjo, Satjipto, 1986, Ilmu Hukum, Bandung: Alumni

Soekanto, Soerjono, 2014, Faktor-faktor yang Mempengaruhi Penegakan Hukum, Jakarta: Raja Grafindo Perkasa

\section{B. Internet}

Mengutip buku Naskah Akademis Penelitian Contempt of Court 2002 terbitan Puslitbang Hukum dan Peradilan Mahkamah Agung RI (h. 7) dalam http://www.hukumonline.com/klinik/detail/1t514052dfdcf3b/definisi-contempt-of-court, diakses hari Sabtu, 23 Januari 2016: 12.32

Background Paper on Freedom of Expression and Contempt of Court, “International Seminar onPromoting Freedom of ExpressionWith the Three Specialised International Mandates” London, United Kingdom, 29-30 November 2000, p. 12 https:/www.article19.org/data/files/pdfs/publications/foe-andcontempt-of-court.pdf

\section{Peraturan Perundang-undangan}

Kitab Undang-undang Hukum Pidana (KUHP)

Kitab Undang-undang Hukum Acara Pidana (KUHAP)

Undang-Undang Nomor 14 tahun 1985 Tentang Mahkamah Agung (Lembaran Negara Republik Indonesia Tahun 1985 Nomor 73, Tambahan Lembaran Negara Republik Indonesia Nomor 3316), sebagaimana telah diubah terakhir dengan Undang-Undang Nomor 3 tahun 2009 tentang Perubahan Kedua Atas Undang-Undang Nomor 14 Tahun 1985 tentang Mahkamah Agung (Lembaran Negara Republik Indonesia Tahun 2009 Nomor 3, Tambahan Lembaran Negara Republik Indonesia Nomor 4958)

Undang-Undang Nomor 48 Tahun 2009 tentang Kekuasaan Kehakiman (Lembaran Negara Republik Indonesia Tahun 2009 Nomor 157, Tambahan Lembaran Negara Republik Indonesia Nomor 5076) 